\title{
The Positive Impact of Inter-Organizational Networking in Innovation in Biotechnology Industry: Comparative Case Analysis of Biotech Network One Nucleus
}

\author{
Vivek Verma \\ School of Economics and International Business \\ University of Greenwich, Park Row, London, United Kingdom \\ Vasilki T Zoumpa \\ School of Economics and International Business \\ University of Greenwich, Park Row, London, United Kingdom
}

\begin{abstract}
To further substantiate the role of inter-organizational networking in innovation, we explored the positive impact of large networks on innovation in the biotechnology industry. The research was conducted in two parts. In the first part, a qualitative research methodology using exploratory case study is performed on the three SME members of the UK-based biotech network One Nucleus. In the second part, a quantitative research approach using comparative empirical OECD data analysis is performed. The two research methodologies used are subsequently linked together thorough a unique research approach known as processual research. A new insight is explored regarding issues linked to inter-organizational networking, like the role of networks on organizational learning, the role of third party organizations within networks, diversity of partners and the nature of learning (localized vs. global) within biotech networks. The primary data is generated on the number of alliances, types of alliances and types of innovation, whereas innovation is measured as a dependent variable. Empirical results obtained clearly indicate that innovation output (patent approval rate, patent success rate) with respect to each alliance made by the sample firms is positively impacted by the parent biotech network One Nucleus.
\end{abstract}

Keywords: Inter-organizational networking, innovation, biotechnology industry, processual research, OECD, innovation output.

\section{INTRODUCTION}

B iotechnology is a multi-billion global industry; it encompasses several sectors or fields of applications, with several different research technologies or innovations. Innovation is indispensable for economic growth (Schumpter, 1934); therefore, it is not surprising that in highly technology-based industries like biotechnology, innovation is regarded as a mantra of success. Biotechnology has revolutionized the conventional knowledge of the pharmaceutical industry with new discoveries in novel areas like drug delivery, molecular genetics, immunology and cell biology (Gans and Stern, 2004). Powell, Koput and Doerr (1996) argued that the knowledge base
Journal of Technology Management for Growing Economies

Vol. 3 No. 2

October 2012 pp. $55-88$

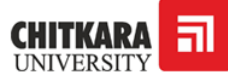

C 2012 by Chitkara University. All Rights Reserved. 
Verma, V.

Zoumpa, V. T. of the biotech industry is both complex and expanding; rather than capitalizing on the success of individual firm, the locus of innovation will be found in interorganizational networks. Innovation is widely accepted as a collective process in which rapid technological changes and inter-organizational networking play an important central role (Smith and Powell, 2004). A substantial amount of theoretical and empirical research on the role of networking has been done in the last two decades. Networking, either external or internal, creates a tacit flow of knowledge, which is vital for innovation. The knowledge shared by either informal or formal communication between collaborating firms leads to collective invention, which fosters innovation (Allen, 1983). To sustain innovation firms has to rely more on external collaboration, the boundaries of the firm get faint as firms become integrated within large networks and assume a central role within these networks and uses continuous knowledge flow to sustain their innovation processes (Smith and Powell, 2004).

Despite a continuous flow of innovation, newly developed biotech firms generally find it difficult to sustain the innovation process in early phase of their industry life cycle. (Accenture and Babson College, 2004). Baker's (2003) research shows that Biotech companies face organizational challenges in sustaining their innovation process as their products move down the pipeline. The integration of biotech firms with large biotech networks overcomes organizational challenges and helps firms to form formal or informal alliances, which foster innovation. Inter-firm networking has its advantages as well as its disadvantages. The sharing of knowledge and ideas within different firms increases the competence of firms; on the other hand, networking does not always prove beneficial. Sometimes networking makes it difficult for the firms to achieve innovativeness and desired profitability (Ozman, 2009).

Chin (2004) underlined the importance of field-based medical science liaisons. Co-operation and exchange of information between different organizations is considered an important special force in biotech innovation. Garcia and Velasco (2005) studied the effect of cooperation networks and geographic clustering on innovation performance. They argued that the critical resources, such as technological knowledge spillover, downstream competence of product development and finance, may represent micro mechanisms for the improvement of the innovation capability of the biotech firm.

The knowledge spillovers generally resulted from informal communication among biotech companies and could lead to collective invention of ideas, products and processes (Allen, 1983). Inter-organizational networking generally depends on the type of industry: Each specific industry setting influences the shape of the network structure (Kogut, 2000). The emergence of a specific network structure largely influences the creation and evolution of

Journal of Technology Management for Growing Economies, Volume 3, Number 2, October 2012 
technology (Soh and Roberts, 2003). A closer look at the available literature

The Positive describes the network of firms in various ways. Granovetter (1998) explained Impact networking in business groups, where firms are bound together in the form of informal and formal relationships. This type of relationship is neither strong, because firms in business groups are generally consolidated into a legal single entity, nor is this relationship weak, as firms benefit from short-term strategic alliances. The locus of innovation is embedded in the network of inter-organizational learning and the creation of knowledge-sharing networks for sustained business practices among highly technological firms (Powell, Koput and Smith-Doerr, 1996). Ring and Van DeVen (1994) and Oliver (1990) explained the inter-organizational relationships for cooperation and sharing of tacit knowledge among technological firms. DeBresson and Amesse (1991) described inter-organizational networking as a linking of innovators in strategic inter-firm network partnerships.

In our research paper, we presented an in-depth investigation of the role of large networks in fostering innovation. The qualitative research approach applied in this paper involved open-ended exploratory telephone interviews for primary data collection and a case study analysis of three sample firm members of the biotech network One Nucleus. The quantitative approach was utilised in the empirical analysis of country-specific OECD (Organization for Economic Co-operation and Developement) indicators in the biotech industry. Our research aims to bridge the gap in the literature, where the primary focus is on the impact of networking on product innovation and largely ignores the relationship between process and organizational innovation. The network innovation research is also relevant because it explores the changing dynamics and configurations of inter-organizational networking. The findings of this paper can be useful for future researchers who aim to study the industry in different period of time. Moreover, this research provides fresh insight into the issues linked to inter-organizational networking. New insight is obtained on the important aspects of networking, such as organizational learning, diversity of partners, the role of third party organizations in collaboration, the types of alliances and the nature of learning for sample biotech firms in the large biotech network 'One Nucleus'. The overall relevance of this research paper is to substantiate the fact that the innovation output of three sample firms (AERES Biomedical Ltd., AnGes Inc. and Polytherics Ltd.) is positively impacted by a number of alliances with organizations within and outside the biotech network One Nucleus. The network One Nucleus was formed in April 2001 by the merger of two life science networks, the London-based London biotechnology network (BioLondon) and Cambridge-based ERBI. The merger created Europe's largest clinical, academic and commercial powerhouse, 
Verma, V.

Zoumpa, V. T. which resulted in several benefits for member firms, research centres and Universities, like support for business-to-business interaction, enhanced competitiveness at the global and local levels (through shared organizational learning and knowledge transfer) and fostering of innovation.

\section{LITERATURE REVIEW}

Early innovation theories of the 1950s and 1960s considered R\&D the

knowledge to be its core competence in sustaining growth and profit and largely ignored external market forces (Lippitt, Watson, and Westly, 1958). A later theory by Clark (1979) contradicted this notion and considered market forces the primary driver of innovation, assigning R\&D a merely secondary role. With globalization, the complexities of international business became apparent. In the globalized world of inter-connectedness, where the benefits and gains of one country are dependent on the benefits and gains of other country, firms struggled to sustain their innovation models. Therefore, new theories of integrated organizational approach gained wide attention, and the need for a new integrative theoretical model led to the emergence of growing network research. New theoretical innovation models highlighted the importance of inter-organizational networks, where innovation is accepted as a collective process (Edwards, 2000; Johnson et al., 2001; Meyer and Mugge, 2001). This assumption sounds good, if we consider the strategic options of global firms, which are focusing on building inter-firm networks to sustain their innovativeness, profitability and performance. In the last decade, global firms have been involved in building network of relationships, which is evident from increased merger and acquisitions activities, R\&D alliances, franchising, licensing or other types of know-how trading interactions at a local or a global level (Ozman, 2009).

\section{Why Firms Collaborate?}

Oliver (1990), in his pioneering research paper, thoroughly explained the motives and reasons behind the collaborations. Organizations are motivated to form collaborations for the following reasons: (1) urgency within the firms to meet regulatory or legal requirements; (2) exploring the opportunities to control another organization; (3) exploring the opportunities of collaboration rather than control (horizontal linkages preferred over vertical); (4) efforts of the organization to enhance its competence and to increase its internal inputoutput ratio; (5) response to economic uncertainty by gaining stability; and (6) gaining legitimacy by improving prestige, image and reputation. Existing industry conditions and the type of collaborative activity largely influence 
the importance of the reasons discussed above. For example, in the case of biotechnology, joint ventures are the main objective behind collaboration.

They overcome the effect of asymmetry and ultimately, larger firms exercise organizational control over smaller firms (Kogut, 1988).

\section{Resource Interdependence}

The resource-based approach proposed by Wernfelt (1984) is the most widespread and earliest approach that explains why firms collaborate. According to this view, firms collaborate to gain interdependence in resource utilization. This view is much in accordance with the findings of Pfeffer and Salancik (1978), and later Hagedoorn (1993) justified this view. The resource-based approach motivates those firms that are not self-sufficient to form alliances with other firms to gain access to each other's resources. The overall repercussion of collaboration is that it reduces uncertainty within the technologically intensive firms and makes them self-sufficient in the optimal utilization of resources. In the biotech industry, the main factor that motivates companies to form inter-organizational relationships is the multidisciplinary character and complexity of the knowledge base (Hagedoorn, 1993). The large and established pharmaceutical companies mostly prefer strategic alliances, as this gives them an opportunity to access the markets and knowledge bases of small firms (Arora and Gambardella, 1990; Shan, Walker, and Kogut, 1994; Walker, Kogut, and Shan, 1997). Arora and Gambardella (1994) researched the findings for the biotech industry and found that a firm's technological capability increases the number of collaborative agreements, while scientific capability reduces their number. This resource-based view supports the most pragmatic thinking behind the fostering of innovation due inter-organizational networking. The creation of inter-organizational clusters brings technological firms, investors, specialized suppliers, universities and schools together to form a densely connected critical mass, where social capital is expressed to generate a knowledge flow (Prahalad and Mashelkar, 2010).

\section{Organizational Learning}

The pioneering research paper that explained the role of inter-organizational networking in the creation of innovation in biotech industry is by Powell, Koput, and Smith-Doerr (1996). Their research placed the concept of organizational learning at the epicentre of the network literature. According to their research, alliance formation leads to the vital process of organizational learning. The technological firms collaborate not only to access resources of each other, but also to exploit and explore the knowledge base, which leads 
Verma, V.

Zoumpa, V. T. to the process of organizational learning. Thus, organizational learning is both a function of creating new capabilities for exploiting tacit knowledge and creating organizational channels to access such knowledge (Powell, Koput, and Smith-Doerr, 1996). The expansion and exploitation of existing knowledge is largely complemented by external collaborations, which directly build internal capabilities within organization to effectively explore the possibilities of business from new knowledge (Mowery, 1989). Collaboration not only strengthens internal competencies but also enhances organizational learning about new technological developments; thus, the locus of innovation is embedded in the inter-organizational networks of learning (Powell, Koput, and Smith-Doerr, 1996). Oliver (2001) studied the exploitation and exploration alliances in the context of the life cycle of the firm. The external conditions like the growth phases of the firms or the stages in industry life largely motivate firms to collaborate. Lavie and Rosenkopf (2006) investigated the role of absorptive capacity and organizational inertia within firms in balancing the exploitation and exploration alliances. As pointed out earlier, collaborations are not always useful because there are indeed negative consequences of knowledge transfer. The type of partnership is related to the innovativeness of the firm: Firms that are technologically more innovative usually restrain the transfer of tacit knowledge by forming a diverse range of partnerships (Dutta and Weiss, 1997). Oxley and Sampson (2004) studied the negative impact of unintended leakage in vital technologies, which hamper R\&D alliances and force firms to become competitors rather partners. This perceived anomaly in alliance, especially in communications and electronic equipment firms, is generally overcome by limiting the scope of alliances and by regulating the flow of knowledge. This dual character of organizational learning was researched by Mohr and Sengupta (2002); their research investigated the negative impact of unintended transfer of knowledge on collaboration and the long-term innovation process.

\section{External factors}

Other factors like external uncertainty, size of the firm, life cycle of firm and industry, type of alliance and firm social ties influences firm's performance, capabilities and innovativeness. Gulati and Higgins (2003) examined the case of young biotechnology firm and its IPO performance, their work shows that linkage benefits of investment bank and venture capital depends on the growth phase of the firm or the stage in the industry life cycle. Studies by Beckman and Haunschild (2004) examine the motivation for exploitation versus exploration alliances in the context of industry life cycle, life cycle of the firm and external environmental uncertainty. Their research clearly shows

Journal of Technology Management for Growing Economies, Volume 3, Number 2, October 2012 
that external conditions like life cycle of the industry and life cycle of the firm forces firms to collaborate.

\section{Diversity of Partners}

Dutta and Weiss (1997) examined the relationship between the innovativeness of the firm and the type of partnership involved. Their study highlighted the importance of diversity in the partner selection choice exercised by the firm; the more diverse the partner is, the greater the ease of regulating and restraining the flow of tacit knowledge. Studies carried out by Baum et al. (2000) show that when start-up biotech firms form networks of relationship with different organizations like universities, research institutes and other firms, their performance increases. The added competencies of diverse partners are very helpful in generating radical innovations. However, studies carried out by Goerzen and Beamish (2005) show the negative impact of partner diversity: in the case of multinational firms, the large partner diversity creates conflicts between partners and lowers the multinational firms' performance.

\section{Effect of geographical proximity}

Geographical proximity plays an important role in the diffusion of innovation. Studies carried out by Aharonson et al. (2004) validate this point, and a case study on biotech firms shows that clustered firms have face-to-face contacts and are in the central position of their knowledge network, which increases their innovativeness. The evolutionary view of innovation considers the firm as a central force in shaping the regional innovation performance. This localized nature of learning within a fixed geographical region fosters innovation and a firm's performance (Capello, 1999). Geographical proximity allows firms to facilitate the diffusion of innovation (Porter, 1990). The latest research by Whittington and Smith (2009) further substantiated previous findings. Their study explains that the importance of external agencies, geographic propinquity and external network position enhances patenting activities and organizational innovation. The proximity of a biotech firm to external public sector knowledge centres such as universities and research institutes stabilizes its regional and global networking. Geographical proximity between inventors is mostly relevant in a situation of knowledge exploration, when knowledge is predominantly tacit (Anne and Wal, 2011). After discussing the issues linked to inter-organizational networking, we propose our first hypothesis.

Hypothesis 1: Inter-organizational alliances within large biotech networks foster innovation among biotech firms because they address the core issues of 
Verma, V.

Zoumpa, V. T. resource interdependence, organizational learning, diversity of partners, type of alliances and nature of learning (localized vs. global).

\section{Product and process innovation}

Commercializing and developing a new product involves large $R \& D$ costs. To cut these costs, biotech firms often collaborate with universities, research centres and R\&D labs. Research done by George, Zahra and Wood (2001) shows that biotech companies that are not members of large biotech clusters often have large R\&D budgets but low innovation output. They analyzed 2457 alliances undertaken by 147 biotechnology firms, and the research results show large patent filing activities in these sample firms, with high innovation output. In technology-intensive industries, process innovation generates product innovation; therefore, product and process innovation systems are inter-related and their interaction is explained by a system dynamic approach (Milling and Stumpfe, 2000). The biotech firm's competencies are determined by its ability to foster innovation in its product portfolios. A product life cycle is generally short, and it becomes essential for biotech firms to enhance their process innovation capacity to generate more innovative products (Psiano, 1997). The available scientific literature focused either on product innovation or on process innovation, without clearly considering the interaction between them. The process innovation in the biotechnology industry has an incremental impact on overall product innovation. The fundamental idea of this concept has been widely explored by previous researchers, and their findings are currently available in innovation literature (Butler, 1988; Ettlie, 1995; Damanpour and Gopalakrishnan, 1999). After discussing the impact of network on product and process innovation, we propose following hypotheses:

Hypothesis 2: Inter-organizational alliances positively impact the overall innovation output of biotech firms.

Hypothesis 3: Large biotech networks positively impact the innovation output of their member firms because the networks allow member firms to form different types of inter-organizational alliances based on their requirements.

\section{METHODS AND DATA}

In this research, both qualitative and quantitative methods are used. Both research methods are appropriate to address the main research questions. The qualitative processual research (Orton, 1997; Pettigrew, 1997) method is used mainly to gain new insights from sample biotech firms on the different aspects linked to inter-organizational networking. The quantitative meta-

Journal of Technology Management for Growing Economies, Volume 3, Number 2, October 2012 
analysis research method (Wolf, 1986) is used to empirically prove the positive impact of inter-organizational alliances on the overall innovation output of the sample firms, members of the biotech network One Nucleus. Using both research methodologies provides enough reliability to the final outcome of this research. Both research methodologies are bridged together by using a specific interpretive method known as processual research (Hinings, 1997; Orton, 1997) and validated by the quantitative meta-analysis research method (Wolf, 1986). Organizational phenomena such as inter-organizational networking is best studied through processual research. The methods of inductive grounded theory (Strauss and Corbin, 1990) shaped the methods of processual research. Like inductive grounded theory, processual research obtains data inductively and contextualizes it to generate an initial theory. Inductive organizational studies, which are "data rich, theory poor", are researched by using processual research (Orton, 1997). The primary data generated through semi-structured in-depth interviews (inductive research method) and the secondary data acquired from reliable valid data resources (deductive research method) are interpreted to generate insights and theory without conflict or the notion that two methods of opposite orientations are used. Orton (1997) supported the use of processual research in iterative grounded theory. Fox-Wolfgramm (1997) used this theory for comparative case analysis. Though processual research alone limits the reliability of the method, it is complemented with the meta-analysis quantitative method of research (Wolf, 1986). The statistical procedures are applied to collect empirical findings from individual studies for final integration and synthesis of valid results in the meta-analysis research method.

\section{Qualitative Research Methodology}

To gain new insight on the important issues of inter-organizational networking, interpretive qualitative research methodology is followed because it provides a holistic view of wide organizational issues. Since this part of our research is primarily a case study research, the pure qualitative approach developed by Patton (1990) is adopted. Semi- structured interviews with respondents from three sample firms are conducted and their views are recorded on a number of core issues linked to inter-organizational networking, like resource-based view, organizational learning, types of innovation (product and process), the importance of diversity of partners, the role of third parties in collaboration, types of alliances and the nature of learning (localized vs. global).

We conducted the exploratory study on the impact of inter-organizational networking on innovation in London for three reasons. First, London is one of the world's most successful cities in attracting international companies, venture

Journal of Technology Management for Growing Economies, Volume 3, Number 2, October 2012
The Positive Impact 
Verma, V.

Zoumpa, V. T. capitalists and specialized services. Second, London is home to successful biotech firms, Small and medium sized enterprises (SME's), large pharma companies, universities, medical schools, facility incubators, etc., hospitals, research institutes, government agencies and other business funding agencies. Third, all these organizations are part of the London biotechnology network now known as One Nucleus. The interview format selected is open-ended indepth semi-structured interviews. The selected themes of this research were explored by using this type of interview format because it could be easily directed toward the chosen theme. The open-ended research approach left the respondents free to express their views openly. Moreover, this format allows us to explore the organizational and other contextual issues that cannot be explored by using questionnaire surveys. For primary research purposes, we contacted 17 Biotech SMEs (members of the One Nucleus biotech network) to arrange face-to face-or telephonic interviews to carry out an open-ended exploratory study. Out of 17 , only three companies gave permission. Therefore, the samples for primary research are three SMEs:

(1) AERES Biomedical Ltd.

(2) AnGes Inc.

(3) Polytherics Ltd.

Three interviewees, $\mathrm{ABC}, \mathrm{XYZ}$ and $\mathrm{DEF}$ (names were kept anonymous due to pre-interview agreements of anonymity), from three sample SMEs, were contacted by e-mail to arrange face-to-face or telephonic interviews to carry out an open-ended exploratory study. Conducting telephone interviews has a great advantage, as it is the most economical way due to its low cost. They also tend to be conducted faster. In terms of questions, all but the most complex kinds can be asked over the telephone. Respondents were asked to share their views on the role of large biotech networks, inter-organizational alliances for the development of biotech, the role of third parties in alliances, the importance of diversity among partners, the nature of learning, the influence of collaborating firms, and the types of ties and embeddedness of firms within the network. The questions most asked of respondents were: (1) Why did your firm collaborate with other organizations within and outside the One Nucleus group? (2) What were the roles of third party firms/organizations in your partnership agreements? (3) What kind of partnership agreements does your firm hold with other firms/organizations? (4) How diverse are your partners? (5) What kind of ties do you have with your partners within the network?

Journal of Technology Management for Growing Economies, Volume 3, Number 2, October 2012 
(6) How has the geographic location of your partner organization influenced your firm's overall innovation output? The respondents' views gave us a clear view of their firms on the issues of collaboration, organizational learning, social connection and embeddedness. The respondents also shared their views on the issues of influence and imitation, diversity of partners, social connection (strong ties), structural holes (weak ties), and the nature of learning (localized vs. global). A special emphasis was to collect primary information on the number of alliances, number of patent applications filled, number of approved patents and number of successful patents. Since this research is "data rich, theory poor", the primary data generated from interviews was validated by tracking the source of news and press releases of each sample firm. Important technical information collected was validated by obtaining online access to each sample firm's databases, which contain all relevant information on alliances, patented technologies and products. The theoretical information collected on issues linked to inter-organizational alliances was also validated by triangulation. Data triangulation validates primary data with data generated from reliable data sources like press releases and firms' internal login portals. The respondents' responses were recorded using a portable audio device. Since the interviews were semi-structured, the main categories for the study analysis (e.g., type of innovation, role of third party, diversity of partners, types of alliances, number of alliances) were predetermined. Raw data were sorted out under separate headings for an effective analysis (Perreault and Leigh, 1989). The primary data collected on the number of alliances and type of alliances were tabulated separately in a table. A special coding scheme was developed to sort out the numbers of each type of alliance. This paper assumes partner biotech firms that are involved in $R \& D$ and commercialization as common entities under the heading of Business and R\&D organization and gives them score of 1 each. Research institutes and universities that are involved in pure research are considered as common separate entities under the heading of Knowledge centre organizations and are scored as 1 each, also. Similarly, venture capitalists and funding organizations are considered as common separate entities under the heading of funding organizations and are scored as 1 each; in the same way, regulatory and legal firms are considered as common entities under the heading Legal organization and are scored as 1. Types of alliances are coded with abbreviations, e.g., licensing agreement as LA, research agreement as RA, manufacturing and marketing agreement as MMA, etc. 
Verma, V.

Zoumpa, V. T.

The primary data on the number of alliances and types of collaboration agreements of each sample firm are recorded in tables, whereas the emerging point of view of interviewees on the core issues linked to inter-organizational networking were theoretically conceptualized into key propositions. These propositions are the key findings of this open-ended exploratory qualitative research. The processual research allows research questions to undergo variation because data analysis itself shapes the research design in advance, and the researcher might not be asking difficult questions (Fox-Wolfgramm, 1997, p. 432). In this research, the viewpoint of respondents is very much biased on the different issues of networking. These wide discrepancies led to limited findings, with only two key propositions that can be said to be valid for the whole industry settings. The small sample size and time and money constriction restricted our efforts to contact sample firms more than once, thus limiting the reliability.

\section{Research findings and Data Analysis}

This part of our research mainly focus on analysis of qualitative data through detailed descriptions of the sample firms' views on a variety of issues linked to inter-organizational networking. The analysis is presented in a systematic pattern according to the real findings in complex behavioural settings. The key findings are then conceptualized as key propositions, whereas primary data related to each sample firm are compiled and presented in tabulated format.

\section{Sample Firm 1: AERES Biomedical Limited}

The company is part of the One Nucleus network. On telephonic interview, the company's former CEO (name is kept anonymous due to company's code of compliance in sharing information with outside network individuals/ organizations) shared his views on the broad issues of networking. The main reason explained by the AERES former CEO (currently holding an important position within the company) for having collaboration with other firms within and outside the One Nucleus group is to share the firm's clinically proven technology of antibody humanization to commercially develop therapeutic antibodies for debilitating and life-threatening diseases. This response highlighted the importance of the resource-based view of networking discussed in the literature review. Research findings indicate the effective role of the parent network One Nucleus in providing desired partners for sample firms; the network is helping firms in linking their process

Journal of Technology Management for Growing Economies, Volume 3, Number 2, October 2012 
innovations with product innovation by allowing them to form collaborative agreements with desired partners. The most surprising issue that emerged from the telephonic interview was the company's unwillingness to form new agreements on behalf of third party collaborators. This response points suggests a weak social connection and partial embeddedness of AERES within its network, which could limit the firm's profitability and innovativeness in the long run, but to prove this assumption more detailed research is required, which is beyond the scope of this research paper. AERES Biomedical Limited has an average diversity in its partners, as most of its partners are small or mediumsized biotech firms. Most of the alliances of AERES Biomedical Limited with its partners (Business, R\&D) are for co-development of new products. The company had 32 collaborative alliances.

Primary data obtained for AERES Biomedical on number and types of alliances are given in table 1.

Table 1: Primary data obtained for AERES biomedical on number of alliances and type of alliances

\begin{tabular}{|c|c|c|c|c|}
\hline $\begin{array}{l}\text { AERES Biomedical } \\
\text { Limited }\end{array}$ & $\begin{array}{l}\text { Major Partner } \\
\text { Business, } \\
\text { R\&D org (Avg } \\
\text { score=1) }\end{array}$ & $\begin{array}{l}\text { Partner Knowl- } \\
\text { edge organization } \\
(\text { Avg score }=1)\end{array}$ & $\begin{array}{l}\text { Partner Funding } \\
\text { organization } \\
(\text { Avg Score }=1)\end{array}$ & $\begin{array}{l}\text { number of } \\
\text { alliances } \\
\text { (Total Score) }\end{array}$ \\
\hline \multicolumn{2}{|c|}{$\begin{array}{l}\text { 1) Acorda Therapeutics (USA) } \\
\text { 2) Antisoma (UK) } \\
\text { 3) Biotest Pharma (Germany } \\
\text { 4) Peregrine Pharma (US) } \\
\text { 5) National Cancer Institute (USA) } \\
\text { 6) Syngenta Biopharma (Switzerland) } \\
\text { 7) Lpath therapeutics (USA) } \\
\text { 8) Greenovation biotech (Germany) } \\
\text { 9) GENOVAC. (Germany) }\end{array}$} & $\begin{array}{l}\text { 1) National Cancer } \\
\text { Institute (USA) } \\
\text { 2)MRC Laborato- } \\
\text { ry of molecular } \\
\text { biology, } \\
\text { Cambridge Uni- } \\
\text { versity }\end{array}$ & $\begin{array}{l}\text { 1)National } \\
\text { Cancer Institute } \\
\text { (USA) }\end{array}$ & $9+2+1=12$ \\
\hline \multicolumn{2}{|c|}{$\begin{array}{l}\text { Total major alliances }=9 \\
\text { Other alliances }=20, \text { total }=12+20=32\end{array}$} & +2 & +1 & $\begin{array}{l}=12 \\
=32\end{array}$ \\
\hline
\end{tabular}

Table 1 Data obtained from AERES Biomedical Ltd office by electronically.

Note: most of the alliances of AERES biomedical limited with its partner (Business, $R \& D)$ are for co-development of new products.

\section{Sample firm 2: AnGes Inc.}

AnGes Inc. is also a knowledge-based company and a part of One Nucleus biotech network, which exploits its expertise of developing novel molecular 
Verma, V.

Zoumpa, V. T. drugs by closely cooperating with pharmaceutical companies. According to the respondent, the company is collaborating mainly to take its drug development projects, which are in different stages, to another level. The respondent reveals that the network provides access for prospective partners in different product development stages, especially in application research and preclinical and clinical phases (i, ii, iii). The company is generating much of its revenue from royalties on its patented products. The licensing agreements, developmental assistance, initial contracts and principal payments have kept the company alive in sustaining its profitability and innovation model; thus, the company has both product and process innovations at its core. The respondent revealed that collaborations sometimes are not sustainable, as collaborating organizations sometimes breach the obligations under the agreement. The respondent revealed that AnGes Inc. had to terminate its licensing agreement with Transcription Factor Therapeutics Ltd. due to breaching of agreement by the firm. The respondent confirmed three methods of collaboration for sustaining innovation. This view of the respondent echoed the firm's ongoing collaboration with industry, academia and government. This information shared by the respondent clearly shows the diversity in its partners, strong ties (rich social capital) and strong embeddedness of the firm in its organizational network. The respondent was clueless on the role of third party collaboration; instead, he pointed out direct alliances that the company holds with its partners. The most surprising fact that emerged from this interview was that the company identifies its Japanbased collaboration as quite fruitful in generating radical innovation; this view of the respondent is evident from the successful generation of patents by AnGes Inc. in Japan. This view of the respondent clearly highlighted the localized nature of knowledge in generating radical innovation, though the firm had to seek more collaboration for manufacturing, marketing and distribution in markets outside Japan. The company mostly has marketing and distribution agreements, investment agreements, research agreements, manufacturing agreements, manufacturing and marketing agreements, licensing agreements, technology transfer agreements and development agreements with its partner organizations. The company had 36 collaborative alliances. Primary data obtained from AnGes Inc. on the number and types of alliances are given in table 2 .

Journal of Technology Management for Growing Economies, Volume 3, Number 2, October 2012 
Table 2: Primary data obtained from AnGes Inc on the number and type of

The Positive alliances

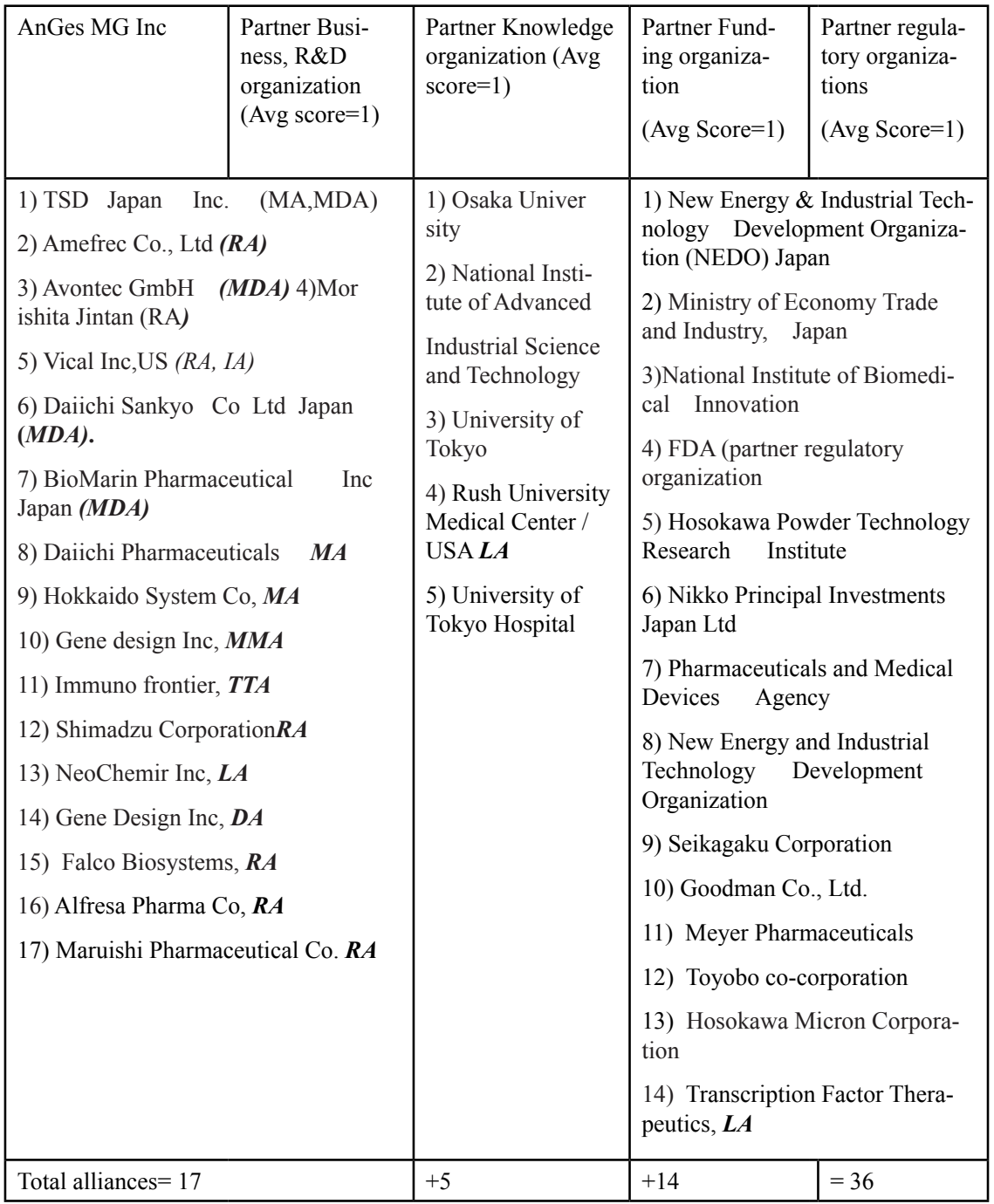

Table 2 Data obtained from AnGes Inc office by electronically. Abbreviations: MDA (Marketing and distribution agreement), IA (Investment agreement), RA (Research Agreement), MA (Manufacturing Agreement), MMA (Manufacturing and Marketing Agreement), LA (Licensing Agreement), TTA (Technology transfer agreement) and DA (Development agreement. 
Verma, V.

Zoumpa, V. T.

\section{Sample Firm 3: Polytherics Ltd.}

Formed in 2002 as a spinout company from London School of Pharmacy and Imperial College London, the company is competent in developing protein and peptide-based drugs. The business strategy of Polytherics has positioned its business to work in collaboration with biopharmaceutical companies to produce better products. Polytherics is part of the One Nucleus group and within this network, the company has expanded its exploratory research under grant-funded initiatives. On the issue of collaboration, the respondent was of the firm view that collaborations are the lifeblood for SMEs. Without collaboration, it is very difficult to obtain seed funding for research and later, business partners for the licensing of technology. This view of the respondent further validates the resource-based view for collaboration, where firms collaborate to gain resource interdependence. The respondent further confirms that the firm is involved in both exploitation and exploration of its ties with its partners. According to the respondent, the biotech network One Nucleus has provided easy access for prospective partners and has made its collaboration with desired partners well before the products are in their phase iii clinical trials. On the issue of the role of third parties in alliances, the respondent confirmed that most of its ties are based on mutual agreements and third parties have negligible roles in their ongoing and previous partnerships. According to the respondent, Polytherics has good diversity in its partners, ranging from industry and academia to governmental organizations. Most of the funding for Polytherics is from private and public funding organizations; this response is evident from the fact that private funding organizations like Imperial Innovation Group (Technology Development and Investment Company) and public funding bodies like the Biotechnology and Biological Sciences Research Council are involved in financing the research and product development activities of the firm. Polytherics mostly has licensing agreements, research agreements and manufacturing agreements with its partners. The company had alliances within and outside the One Nucleus group. While most of the partner knowledge organizations are within the One Nucleus Network, partner funding organizations are outside the network. The firm has 22 alliances. Primary data obtained from Polytherics on the number and types of alliances are given in table 3 . 
Table 3: Primary data obtained from Polytherics on the number and type of

The Positive

alliances

\begin{tabular}{|c|c|c|c|}
\hline Polytherics & $\begin{array}{l}\text { Partner Busi- } \\
\text { ness, R\&D } \\
\text { organization } \\
(\text { Avg score }=1)\end{array}$ & $\begin{array}{l}\text { Partner Knowledge } \\
\text { organization (Avg } \\
\text { score=1) }\end{array}$ & $\begin{array}{l}\text { Partner funding organiza- } \\
\text { tions } \\
(\text { Avg Score=1) }\end{array}$ \\
\hline $\begin{array}{l}\text { 1) Shantha } \mathrm{E} \\
\text { 2) Celtic Ph } \\
\text { 3) Zealand } \mathrm{F} \\
\text { 4) Isogenica } \\
\text { 5) Biovectra } \\
\text { 6) DSM Bio } \\
\text { 7) Minpharn } \\
\text { 8) Alligator } \\
\text { 9) Biocomp } \\
\text { 10) Avecia } \mathrm{I} \\
\text { 11) BioVectt }\end{array}$ & $\begin{array}{l}\text { lopment) } \\
\text { tion) }\end{array}$ & $\begin{array}{l}\text { 1) Lon- } \\
\text { don School of } \\
\text { Pharmacy } \\
\text { 2) Imperial Col- } \\
\text { lege London } \\
\text { 3) Aston Univer- } \\
\text { sity } \\
\text { 4) Hammer- } \\
\text { smith Hospital }\end{array}$ & $\begin{array}{l}\text { 1) Bloomsbury Bioseed } \\
\text { Fund } \\
\text { 2) Catalyst Biomedica } \\
\text { 3). Imperial Innova- } \\
\text { tions Group plc } \\
\text { 4) Longbow Capital } \\
\text { 5) Regional Venture Capital } \\
\text { Fund for London. } \\
\text { 6) Capital Fund } \\
\text { 7) Biotechnology and Bio- } \\
\text { logical Sciences Research } \\
\text { Council }\end{array}$ \\
\hline \multicolumn{2}{|c|}{ Number of Alliances $=11+$} & +4 & $+7=22$ \\
\hline
\end{tabular}

Table 3 Data obtained from Polytherics office by electronically.

\section{LA (Licensing Agreement), MA (Manufacturing Agreement)}

\section{Research Findings}

The key research findings are as follows:

1) The biotech network One Nucleus has linked the process innovations of all three sample firms with product innovations by providing easy access to them in building various types of inter-organizational alliances.

2) The parent network has allowed sample firms to exploit knowledge of its partners and helped in expanding their existing capabilities. All three sample firms denied the role of third party organizations in forming alliances; rather, they prefer more direct alliances. This finding needs more research, however, as the available sample responses do not convey industry views in accordance with the available research.

3) Research agreements and licensing agreements directly impact innovation output as they create more product innovations by providing desired partners 
Verma, V.

Zoumpa, V. T. inside and outside the network of firms to license their patented process technologies.

Based on the findings of qualitative research, two hypothetical propositions are developed. Both are subsequently tested through quantitative methodology.

Proposition 1: To sustain innovation, biotech companies have to form alliances in the form of co-development/co-promotion, licensing and other research agreements with different organizations within and outside the network.

Proposition 2: The innovation output of the sample firms within the One Nucleus biotech network is positively impacted by the number of collaborative alliances.

The proposed proposition 2 states exactly what was hypothesized earlier in hypothesis 2 of the introduction section; therefore, the propositions made here are not entirely different from the proposed hypotheses. The sample size of the qualitative research is three member firms of the large biotech network One Nucleus. This size is very small and the primary data generated on the number of alliances are insufficient to prove proposition 2 . Therefore, the primary data is analyzed with the secondary data collected from the OECD biotechnology 2009 statistics. The innovation output of the three sample biotech firms within the One Nucleus network is compared with the innovation output of OECD (US, Europe and Japanese) biotech firms.

\section{Quantitative Research Methodology}

A quantitative research approach is used to validate some key findings of the qualitative research; this type of research is known as meta-analysis: quantitative methods of research (Wolf, 1986, p. 11). Meta-analysis means analysis of analyses, rigorous statistical alternatives to the casual narrative discussion of research studies. In this research paper, primary analysis generated a proposition complementing hypotheses 2 and 3 , which are analyzed by meta-analysis of large volumes of OECD data to generate reliable results. In this research paper, secondary reanalysis of statistical data on independent variables, e.g., number of alliances and number of patent applications, is conducted. Innovation is a dependent variable, which depends on the number of alliances; thus data on patents are very helpful in measuring firms' innovation and knowledge diffusion (Nelson, 2009). The number of patents is taken as a dependent variable that directly measures innovation output. Innovation output is measured in terms of the number of successful commercial patents obtained for each number of alliances made by the firm. Since the sample firm level data is not sufficient to generate a plausible conclusion, this research paper takes

Journal of Technology Management for Growing Economies, Volume 3, Number 2, October 2012 
data from OECD biotechnology 2009 statistics. Data is collected for the number of alliances and number of patent applications filed (independent variable). Dependent variables like patent filing application rate, patent approval rate and commercial patent success rate collectively measure innovation output; this dependent variable is measured through proposed empirical equations. The OECD data is a reliable source of information, as it used the UNU-MERIT CATI database to collect information on strategic alliances by multinational and domestic firms for joint research and technology transfer (Beuzekom \& Arundel, 2009).

\section{Variables}

Innovation is a dependent variable that depends on the number of alliances. A data-based systematic layout plan is developed in which the patent application filing rate, patent approval rate and patent success rate are assumed to be dependent variables for measuring innovation output. The impact of independent variables, like number of alliances, on dependent variables is calculated through hypothetical empirical equations.

\section{Independent variables:}

(1) Number of alliances

(2) Number of patent applications filed

\section{Dependent variables:}

(1) Patent application filing rate or initial innovation output

(2) Net innovation output or patent approval rate

(3) Final innovation output or patent success rate

Innovation output is measured in terms of the patent approval rate and patent success rate with respect to each alliance made for research and technology transfer by the sample firm. Since highly reliable data on the independent variables are presented in OECD biotechnology statistics 2009, the collective innovation output for firms in OECD countries like the US, Europe and Japan is determined. In the same way, the innovation output for the biotech network One Nucleus is determined by taking data on independent variables from regional OECD biotechnology 2009 statistics on South England (home of One Nucleus). Finally, the innovation output for sample biotech firms is determined by using primary data. The dependent variables were measured by hypothetical empirical equation. By using the empirical equation, innovation output for OECD members (US, Japan and Europe) is determined. The innovation output for One Nucleus is also determined by using OECD 2009 biotechnology statistics on South East regions of England. 
Verma, V.

Zoumpa, V. T.

The comparative quantitative meta-research analysis of both primary and secondary data, with the help of hypothetical empirical equations, is used in measuring the innovation output of the sample firms. The final inference is drawn based on the results in proving hypotheses 2 and 3. The quantitative meta-analysis research design is very rigid and has limited flexibility to interpret the wide research picture; its focus is limited. This method uses different measuring techniques with different definitions of variables. The poorly designed studies are included with results from good studies; therefore, the results of the meta-analysis are uninterpretable (Glass et al., 1981).

The hypothetical assumption made in proposition 2, which states that the innovation output of the sample firm within the One Nucleus Biotech network is positively impacted by the number of collaborative alliances, is tested by a quantitative research approach. OECD biotechnology statistics (2009) cover alliance data from 1990 to 2006. During this period a total of 1,396 biotechnology alliances were included in the UNU-MERIT CATI database. Table 4 shows the biotech alliances by firms in the US, Europe, Japan and other countries.

\section{Independent Variable: Number of Alliances}

From table 4, it is quite evident that firms in the US had 3013 (75.80\%) of the total (3975) biotechnology alliances for research and technology transfer from 1990 to 2006. In the same period, firms in Europe had 2003 (50.40\%) biotechnology alliances, Japanese firms had $328(8.25 \%)$ and others had $533(13.40 \%)$ alliances for research or technology transfer.

Table 4: Independent variable: number of alliances

\begin{tabular}{|c|c|c|c|c|c|}
\hline \multicolumn{6}{|c|}{ Number of biotechnology alliances for research or technology transfer, 1990 to 2006 } \\
\hline Year & Total & USA & Europe & Japan & Others \\
\hline $\mathbf{1 9 9 0}$ & 45 & 28 & 26 & 6 & 11 \\
\hline $\mathbf{1 9 9 1}$ & 36 & 33 & 18 & 3 & 1 \\
\hline $\mathbf{1 9 9 2}$ & 98 & 77 & 61 & 8 & 11 \\
\hline $\mathbf{1 9 9 3}$ & 124 & 108 & 53 & 15 & 9 \\
\hline $\mathbf{1 9 9 4}$ & 161 & 125 & 95 & 11 & 12 \\
\hline $\mathbf{1 9 9 5}$ & 164 & 127 & 98 & 15 & 12 \\
\hline $\mathbf{1 9 9 6}$ & 177 & 141 & 101 & 20 & 20 \\
\hline $\mathbf{1 9 9 7}$ & 182 & 162 & 76 & 13 & 14 \\
\hline
\end{tabular}

Journal of Technology Management for Growing Economies, Volume 3, Number 2, October 2012 


\begin{tabular}{|l|l|l|c|c|c|}
\hline \multicolumn{6}{|c|}{ Number of biotechnology alliances for research or technology transfer, 1990 to 2006} \\
\hline $\mathbf{1 9 9 8}$ & 147 & 120 & 81 & 11 & 6 \\
\hline $\mathbf{1 9 9 9}$ & 190 & 165 & 83 & 18 & 18 \\
\hline $\mathbf{2 0 0 0}$ & 200 & 165 & 91 & 9 & 22 \\
\hline $\mathbf{2 0 0 1}$ & 355 & 274 & 171 & 17 & 48 \\
\hline $\mathbf{2 0 0 2}$ & 332 & 219 & 177 & 41 & 56 \\
\hline $\mathbf{2 0 0 3}$ & 368 & 274 & 178 & 28 & 52 \\
\hline $\mathbf{2 0 0 4}$ & 389 & 277 & 197 & 32 & 50 \\
\hline $\mathbf{2 0 0 5}$ & 481 & 358 & 217 & 54 & 75 \\
\hline $\mathbf{2 0 0 6}$ & 526 & 360 & 280 & 53 & 96 \\
\hline
\end{tabular}

The Positive Impact

Table 4: Source: UNU-MERIT CATI database, Maastricht, the Netherlands, April 2009. (Accessed from OECD Biotechnology statistics 2009, page 95)

\section{Independent Variable: Number of Patent Applications Filed}

From 1994 to 2006, the US filed 139,261 biotechnology patent applications under the Patent Cooperation Treaty (PCT), whereas the EU in the same period filed 132,327 patent applications. Japan was ranked third, with 68,011 PCT patent application filling (Table 5), Brazil, Russia, India and China (BRIC) accounted for 18,747 biotechnology patent application filings.

Table 5: Independent variable: number of patent applications filed.

\begin{tabular}{|c|c|c|c|c|}
\hline \multicolumn{5}{|c|}{ Biotechnology PCT patent applications and total PCT patent applications } \\
\hline \multicolumn{2}{|c|}{ 1994-1996 } & \multicolumn{2}{|r|}{ 2004-2006 } & \multirow[b]{2}{*}{ Total } \\
\hline Biote & $\log y$ & Total & Biotechnology & \\
\hline USA & 7757 & 56,656 & 11,474 & 139,261 \\
\hline $\mathbf{E U}$ & 3,900 & 54,019 & 7487 & 132,327 \\
\hline Japan & 894 & 10,065 & 3720 & 68,011 \\
\hline BRICS & 92 & 1,899 & 887 & 18,747 \\
\hline
\end{tabular}

Table 5 Sources: OECD, Patent and REGPAT databases, January 2009; and EPO Worldwide Statistical Patent database, September 2008 (Accesed from OECD Biotechnology statistics 2009, page 75)

\section{Dependent variables: Patent application filling rate or initial innovation output}

To determine the relationship between independent variables and dependent variables, this research paper hypothesizes an empirical equation 
Verma, V.

Zoumpa, V. T. $(p A p p) t /(a R T T) t=i$.............(1)

where $i$ is initial innovation output, which in simple terms can be defined as the patent filling application rate, i.e., the total number of biotechnology patent applications filed by a biotech firm for each of its single alliances with other firms/ or research organizations. pApp is total number of patent applications filed by a biotech firm under PCT in specific time period $t$.

aRTT is number of alliances for research and technology transfer in specific time period t. By using equation hypothetical (1), this research paper calculates the initial innovation output (i) for firms in the US, EU and Japan in table 6.

Table 6: Dependent variables: patent application filling rate or initial innovation output

\begin{tabular}{|c|c|c|c|}
\hline $\mathbf{1 9 9 4} 1996$ & (pApp)t & (aRTT)t & (pApp)t/(aRTT)t=i \\
\hline USA & 7,757 & 393 & $7757 / 393=19.73$ \\
\hline EU & 3,900 & 294 & $3,900 / 294=13.26$ \\
\hline Japan & 894 & 46 & $894 / 46=19.43$ \\
\hline \multicolumn{2}{|c|}{$\mathbf{2 0 0 4 - 2 0 0 6}$} & & \\
\hline USA & 11,474 & 995 & $11474 / 995=11.53$ \\
\hline EU & 7,487 & 694 & $7,487 / 694=10.78$ \\
\hline Japan & 3,720 & 139 & $3720 / 139=26.76$ \\
\hline
\end{tabular}

Table 6: Initial innovation output or patent filling application rate.

From Table 6, it becomes quite clear that for each single alliance made by the US biotech firm/research organization from period 1994-1996, it has filed 19.73 biotech patent applications under the PCT. Single alliances had the tendency to generate 19 patent applications ready for filing. In the same way, between 1994 and1996, each single alliance in Europe had the capacity to generate 13.26 patent applications ready for filing, whereas in Japan each single alliance generated 19 patent applications for filing. The empirical results for innovation output from year 2004 to 2006 indicate that the patent filing application rate decreased to 11.53 applications for each alliance made by the US biotech firms or research organizations. The trend in Europe was much like that of the US, where a single alliance generated 10.78 patent applications. In Japan, though, the patent filing application rate was much higher, at 26.76 .

\section{Dependent variables: net innovation output (ni) or patent approval rate}

According to US Patent Office spokeswoman Brigid Quinn (2004), only 60 percent of patent applications are approved; however, the latest empirical

Journal of Technology Management for Growing Economies, Volume 3, Number 2, October 2012 
research conducted by the US Patent Office (2007) indicates that only 54 percent of patent applications are approved; 46 percent are failures. In this

research paper, the second dependent variable (approved patents) is calculated on the basis of 2007 US Patent Office research. The hypothetical equation (ii) below is used to obtain dependent variable net innovation output or approved patents.

$$
\begin{aligned}
& (p A p p) t /(\text { aRTT }) t=i-54 \% \ldots \ldots \ldots \ldots . .(i i) \\
& (p A p p) t /(a R T T) t=n i \ldots \ldots \ldots \ldots \ldots \ldots . .(i i i) \quad(\text { ie } \mathrm{i}-54 \%=\mathrm{ni})
\end{aligned}
$$

Therefore, net innovation output or approved patents $n i$ (dependent variable) can be defined with respect to independent variables, such as patent applications filed and number of alliances by a firm, as follows:

ni is net innovation output, which in simple terms can be defined as the patent approved rate from the total number of biotechnology patent applications filed by biotech firm for its each single alliance with other firms/or research organizations. pApp is the total number of patent applications filed by the biotech firm under PCT in a specific time period, $t$.

aRTT is the number of alliances for research and technology transfer in a specific time period, t. Therefore, $n i$ for each alliance made by the biotech firm is calculated by using equation (ii). Table (7) calculates $n i$ for the US, Europe and Japan from 1994 to 1996 and 2004 to 2006.

Table 7: Dependent variables: net innovation output (ni) or patent approval rate

\begin{tabular}{|l|c|c|cc|}
\hline \multicolumn{1}{|c|}{$\mathbf{1 9 9 4} \mathbf{1 9 9 6}$} & (pApp)t & (aRTT)t & \multicolumn{2}{|c|}{ (pApp)t/(aRTT)t= i-54\%= ni } \\
\hline USA & 7,757 & 393 & $19.73-54 \%=$ & 9.07 \\
\hline EU & 3,900 & 294 & $13.26-54 \%=$ & 6.09 \\
\hline Japan & 894 & 46 & $19.43-54 \%=$ & 8.93 \\
\hline \multicolumn{2}{|c|}{$\mathbf{2 0 0 4 - 2 0 0 6}$} & & & \\
\hline USA & 11,474 & 995 & $11.53-54 \%=$ & 5.30 \\
\hline EU & 7,487 & 694 & $10.78-54 \%=$ & 4.95 \\
\hline Japan & 3,720 & 139 & $26.76-54 \%=$ & 12.30 \\
\hline
\end{tabular}

Table 7 Net innovation output or patent approval rate.

From table 7, it is quite clear that for each alliance made by US biotech firms from 1994 to 1996, they filed 19.73 patent applications. Only 9.07 patent applications were approved. In Europe, the patent approval rate with respect 
Verma, V.

Zoumpa, V. T.

to each alliance was 6.09, and for Japan it was 8.93. From 2004 to2006, the net innovation output or patent approval rate for US biotech firms was 5.30 with respect to each alliance made. In the same time period, the net innovation output or patent approval rate with respect to each alliance made by European and Japanese biotech firms was 4.95 and 12.30 , respectively.

\section{Dependent variable: final innovation output or patent success rate}

Final innovation output $(f)$ or patent success rate measures the commercial success of the patent. This variable is very important for this research paper, as it directly measures the sustainable impact of alliances for biotech firms. Final innovation output (fi) or patent success rate can be defined as:

$f i$ is final innovation output, which in simple terms can be defined as the patent success rate from the total number of approved patents with respect to each single alliance made by a biotech firm/or research organization.

The pioneering research conducted by Harold and Bevolyn (1999) shows that one out of 5000 inventions has a successful product launch. The major research conducted by the US Patent and Trademark Office (2005) concluded that out of 1.5 million patents, only 3000 patents are commercially viable. Later, Mimi Whitefield of the Miami Herald noted that only one out of 100 patented products makes money. The major research studies by Kuczmarski (1991), Brown (1993) and Mukharjee (1998) show that only five percent of patents are commercialized; the remaining $95 \%$ of patents failed to earn money. The empirical equation for dependent variable $f$ (final innovation) or patent success rate is derived from empirical equation (i), as follows:

$$
\begin{aligned}
& (p A p p) t /(a R T T) t= \\
& (p A p p) t /(a R T T) t=i-54 \% \\
& (p A p p) t /(a R T T) t=n \\
& (p A p p) t /(a R T T) t=n i-95 \% \text {. } \\
& (p A p p) t /(a R T T) t=f i \\
& \text { (ie } \mathrm{i}-54 \%=\text { ni) } \\
& (n i-95 \%=f i)
\end{aligned}
$$

The empirical equation (v) shows the relationship between dependent variable (fi) and independent variables (pApp)t and (aRTT)t.

According to empirical equation (v), the final innovation output is the patent success rate, derived from the number of patent applications filed by a biotech firm or research organization at specific time $t$, with respect to each alliance made by the firm for research and technology transfer at specific time period $(t)$.

Journal of Technology Management for Growing Economies, Volume 3, Number 2, October 2012 
On the basis of equation (v), table 8 calculates the patent success rate among biotech firms in the US, Europe and Japan from 1994 to 1996 and 2004 to 2006.

Table 8: Dependent variables: final innovation output or patent success rate.

\begin{tabular}{|c|c|c|c|c|}
\hline 19941996 & (pApp)t & (aRTT)t & \multicolumn{2}{|c|}{$(p A p p) t /($ aRTT $) t=n i-95 \%=f$} \\
\hline USA & 7,757 & 393 & $9.07-95 \%=$ & 0.45 \\
\hline $\mathbf{E U}$ & 3,900 & 294 & $7.16-95 \%=$ & 0.35 \\
\hline Japan & 894 & 46 & $10.49-95 \%=$ & 0.52 \\
\hline \multicolumn{2}{|c|}{ 2004-2006 } & & & \\
\hline USA & 11,474 & 995 & $6.22-95 \%=$ & 0.31 \\
\hline $\mathbf{E U}$ & 7,487 & 694 & $5.82-95 \%=$ & 0.29 \\
\hline Japan & 3,720 & 139 & $14.45-95 \%=$ & 0.72 \\
\hline
\end{tabular}

Table 8 Final innovation output or patent success rate.

From table 8 , it is quite clear that for each alliance made by US biotech firms from 1994 to 1996, they filed 19.73 patent applications; only 9.07 patent applications were approved, out of which only 0.45 patents were commercially successful. In Europe, the patent success rate with respect to each alliance was 0.35 , and for Japan it was 0.52. From 2004 to 2006, the final innovation output or patent success rate for US biotech firms was 0.31 with respect to each alliance made. In the same time period, the final innovation output or patent success rate with respect to each alliance made by European and Japanese biotech firms was 0.29 and 0.72, respectively.

\section{Innovation output for biotech network one nucleus}

In table 9, worldwide regions are ranked based on biotechnology PCT patent applications from 2004 to 2006. Three regions of the UK are among top 30 regions, most notably East England (Rank 19), South-East England (Rank 22) and London (Rank 28). These three regions are very important for this paper's research because most of the member research organizations of the One Nucleus (BioLondon) network are in these regions. Collectively, this region of England accounted for 719 biotechnology PCT patent applications from 2004 to 2006. 
Verma, V.

Zoumpa, V. T.
Table 9: World Wide biotechnology region ranking on the basis of biotechnology PCT patent applications from 2004-2006.

\begin{tabular}{|l|c|c|c|}
\hline \multicolumn{1}{|c|}{ Region (Territorial Level ) } & Country & Patents total & Share (\%)in \\
\hline 1) San Jose-San Francisco-Oakland & US & $\mathbf{1 5 1 0}$ & 5.5 \\
\hline 2) Boston-Worcester-Manchester & US & $\mathbf{1 4 2 2}$ & 5.2 \\
\hline 3) New York-Newark-Bridgeport & US & $\mathbf{1 0 9 0}$ & 4.0 \\
\hline 4) Washington-Baltimore-N.Virginia & US & $\mathbf{8 1 1}$ & 3.0 \\
\hline 5) Tokyo & JP & $\mathbf{7 9 2}$ & 2.9 \\
\hline 6) San Diego-Carlsbad-San Marcos & US & $\mathbf{7 8 2}$ & 2.9 \\
\hline 7) Los Angeles-Long Beach-Riverside & US & $\mathbf{6 1 3}$ & 2.2 \\
\hline 8) Philadelphia-Camden-Vineland & US & $\mathbf{5 8 7}$ & 2.2 \\
\hline 9) Nordrhein-Westfalen & GE & $\mathbf{5 0 6}$ & 1.9 \\
\hline 10)Hovedstadsregionen & DK & $\mathbf{4 5 4}$ & 1.7 \\
\hline TOP REGION OF ENGLAND & GB & $\mathbf{2 6 2}$ & 1.0 \\
\hline 19)East of England & & & 0.9 \\
\hline 22) South-East (England) & GB & $\mathbf{2 4 6}$ & 0.7 \\
\hline 28) London & G & $\mathbf{2 0 1}$ & \\
\hline
\end{tabular}

Table 9: Sources: OECD, Patent and REGPAT databases, January 2009; and EPO Worldwide Statistical Patent database, September 2008 (Biotechnology statistics, 2009 page 71).http://www.oecd.org/dataoecd/4/23/42833898.pdf

We had OECD patent application filing data for the South-Eastern region of England (Table 9), where most of the biotech companies and research organizations are clustered together in networks like London Biotechnology Network (BioLondon) and Cambridge-based EBRI. Collectively this network is now known as One Nucleus. On the basis of the proposed empirical equations, this research paper calculates the innovation output for One Nucleus Network (this network combines both BioLondon and EBRI) for the period from 2004 to 2006. The results are given in table 10 .

Table 10:

\begin{tabular}{|l|c|c|c|c|c|c|}
\hline $\mathbf{2 0 0 4 - 2 0 0 6}$ & $\begin{array}{c}\mathbf{( p A p p )} \\
\mathbf{t}\end{array}$ & Networks & (aRTT)t & I & ni & $\mathbf{f i}$ \\
\hline East of England & 262 & EBRI & 16 & 16.37 & 7.53 & 0.37 \\
\hline South East England & 246 & EBRI & 18 & 11.16 & 5.13 & 0.25 \\
\hline London & 201 & BioLondon & 8 & 25.12 & 11.55 & 0.57 \\
\hline Combined & $\mathbf{7 0 9}$ & One Nucleus & $\mathbf{4 2}$ & $\mathbf{1 6 . 8 8}$ & $\mathbf{7 . 7 6}$ & $\mathbf{0 . 3 8}$ \\
\hline
\end{tabular}

Journal of Technology Management for Growing Economies, Volume 3, Number 2, October 2012 
Table 10: calculates i initial innovation output (patent filling application rate),ni net innovation output (patent approval rate) and fi final innovation output (patent success rate for commercial activity) for South, East and South East region of England from 2004-2006.

\section{Innovation output for sample firms}

Since there are nonexistent data on the number of patent applications filed by each sample firm, the empirical equations developed above cannot be used to measure innovation output. Instead, an alternative direct approach is used, where innovation output is analyzed based on information available on the number of successful patents obtained and commercial patents obtained in generating revenues. The information is later validated by collecting data on the number of approved patents and number of commercial patents. Table 11 shows patent data for sample firms, the patent data collected are from the first year of the company's operations.

Table 11:

\begin{tabular}{|l|l|c|c|c|c|}
\hline Year & SME & Networks & NA & AP & SP \\
\hline 2001-2004 & AERES Bio Ltd & BioLondon & 32 & 70 & 30 \\
\hline $\mathbf{2 0 0 3 - 2 0 1 0}$ & AnGes MG Inc & BioLondon & 36 & 31 & 14 \\
\hline 2005-2010 & Polytherics & BioLondon & 22 & 22 & 7 \\
\hline
\end{tabular}

Table 11: Data on number of alliances (NA) for research and technology transfer, approved patents (AP) and successful patents (SP).

The innovation output for sample firms is calculated from 2004 to 2006. Patent approval rates and patent success rates are calculated with respect to each alliance made by sample firms for research, and technology transfer is shown in Table 11. Since clear data is available on number of approved patents and number of successful patents for each sample firm, patent approval rates and patent success rates are calculated by using equations (vi) and (vii).

$$
\begin{aligned}
& (A P) /(a R T T) t=n i \ldots \ldots \ldots \ldots \ldots \ldots \ldots \ldots \ldots \ldots \ldots \ldots \ldots . . .(v i) \\
& (S P) /(a \text { RTT }) t=f i \ldots \ldots \ldots \ldots \ldots \ldots \ldots \ldots \ldots \ldots \ldots \ldots \ldots \ldots \ldots . . .(v i i)
\end{aligned}
$$


Verma, V.

Zoumpa, V. T.
Table 12:

\begin{tabular}{|l|c|c|c|c|c|}
\hline \multicolumn{1}{|c|}{ SME(2004 2006) } & (aRTT)t & AP & SP & Ni & Fi \\
\hline AERES Bio Ltd & 2 & 18 & 3 & 9 & 1.5 \\
\hline AnGes MG Inc & 3 & 24 & 2 & 8 & 0.66 \\
\hline Polytherics & 2 & 19 & 1 & 9.5 & 0.5 \\
\hline
\end{tabular}

Table 12: Innovation output for sample firms from 2004-2006. $\mathrm{ni}$ (net innovation output or patent approval rate), $f$ (final innovation output or patent success rate for commercial activities).

\section{Comparative analysis of innovation output}

The comparative analysis of innovation output in table 12 clearly shows that the innovation output measured in terms of patent approval rate and patent success rate is much higher for London-based biotech network One Nucleus. Except for Japan, the innovation output for One Nucleus biotech network is higher than the collective innovation output of firms in the US and Europe. The sample firm level data also pointed at improved figures in innovation output. All the three sample firms have higher innovation outputs than the average innovation output of their parent biotech network One Nucleus.

Table 13:

\begin{tabular}{|l|c|c|c|c|c|c|c|}
\hline 2004-06 & \multicolumn{2}{|c|}{ OECD Members } & & Network & \multicolumn{2}{c|}{ SME's } & \\
\hline & US & Europe & Japan & OneNuc & AERES & AnGes & Polytherics \\
\hline $\mathbf{N i}$ & 5.3 & 4.95 & 12.3 & 7.76 & 9 & 8 & 9.5 \\
\hline $\mathbf{F i}$ & 0.31 & 0.29 & 0.72 & 0.38 & 1.5 & 0.66 & 0.5 \\
\hline
\end{tabular}

Table 13: showing comparative innovation output (patent approval rate, patent success rate) among OECD members, sample parent network and sample member firms.

From table 13, it becomes quite clear that the patent approval rate of AERES, AnGes and Polytherics from 2004 to 2006 was 9, 8 and 9.5 for each alliance, respectively. The patent approval rate, which is assumed as net innovation output by the researcher, is comparatively much higher than the collective net innovation output of firms in the US and Europe. Firms in Japan were more innovative than the sample firms in the same time period. The patent success rate or final innovation output was $1.5,0.66$ and 0.5 , respectively, for sample firms with respect to each alliance they made for research and technology transfer. This rate was also quite good in comparison to final innovation rate calculated for firms in the US and Europe.

Journal of Technology Management for Growing Economies, Volume 3, Number 2, October 2012 
The higher innovation output for the sample firms within the One Nucleus network can be attributed to the fact that these sample firms had made effective alliances for research and technology transfer with organizations inside and outside the network. The number of alliances had positively impacted their innovation output, and this fact is clear from their higher patent approval rate and patent success rate with respect to each alliance they made for research and technology transfer (table 11). The apparent benefits for networking for these sample firms were also evident in part 1 of this research dissertation. The sample firms had very good diversity of partners, a minimal role of third party firms in their collaboration and above all, all three firms have good mixtures of product and process innovation. Table 11 also highlighted the power of networks in boosting the innovation output of their member firms. From table 11 it is quite clear that from 2004 to 2006, the innovation output of the biotech network One Nucleus was also very much higher than the collective innovation output of firms in the US and Europe. The positive trend in fostering innovation within the network undoubtedly was transmitted to the member sample firms and they immensely benefitted from inter-organizational alliances within and outside the biotech network One Nucleus in fostering their overall innovation processes.

\section{CONCLUSION}

This study explores the impact of inter-organizational networking on innovation. With this research, we addressed the basic broad question of why companies benefit from inter-organizational alliances within networks in fostering their innovation creation process. However, this research is very much a starting point in understating the impact of inter-organizational networking on innovation. This research used two basic methods for exploring the innovation output of competent sample firms, members of the large biotech network One Nucleus. Based on this research's results and chosen methodology, a more precise research instrument can be designed. The refined research instrument can be included in the long list of other available research instruments for exploring the other aspects of inter-organizational networking. There are two managerial implications from this research. First, this study highlights the importance of inter-organizational networking for firms in handling and managing collaborative alliances for enhancing their overall innovation output. Thus, firms can be advised to analyze different aspects of inter-organizational networking before forming an alliance with the prospective partner. The analysis can be based on analyzing the reasons behind forming the collaboration and identifying the type of innovation the firm held at its inception, whether product or process innovation. Other issues it is advisable 
Verma, V.

Zoumpa, V. T.

84 for firms to look at before forming inter-organizational collaborations include consideration of diversity among prospective partners. Other issues like the role of third party, the nature of learning and the type of alliance, whether licensing, co-development and research agreement, can be advised upon for the newly established biotech firm. Second, this research shows that innovation output can be measured by collecting data on patent approval rates and patent success rates. The empirical methodology developed in this research can be used to identify the positive elements in biotech networks and other partner firms. By using empirical equations, firms can calculate their innovation output with respect to each alliance they form for research and technology transfer. Thus, firms can make an informed decision on their selection of partners and can review the status of their ongoing alliances. Since this research calculates innovation output for sample firms from 2004 to 2006 due to the availability of well-defined OECD data in that time period, the current practical implications of this study, even for the sample firms, remain quite limited. This study can highlight the findings as past trends with future implications. The limitations of this research are two-fold: first, this research fails to develop some conceptual theoretical framework or innovation model that can be said to be applicable to the complex biotechnology industry. The reasons for this failure can be attributed to its small sample size. Moreover, the sample firms are in different stages of their developmental cycle, coincidentally having both product and process innovation at its core. The new insight on different aspects of interorganizational networking gives a rather ambiguous picture instead of a broad consensus on the researched issues. The broad divergence of findings at the firm level restricts the researcher to developing a consensus-based theoretical conceptual model applicable for the whole industry settings. The different aspects related to inter-organizational networking are much broader areas of research that need an individual attempt to study, which is indeed beyond the scope of this research. The positive thing about our research is that we attempted to bring those issues into the single exploratory research, which has partially been achieved, though much of the research questions still remain unanswered or were only partially answered. Second, the empirical equation developed to measure the innovation output of OECD members, One Nucleus and sample firms only takes into account alliances that are meant for research and technology transfer, because these alliances are thought to boost patent output (OECD, 2009). The other alliances such as alliances with funding bodies, regulatory bodies, legal organizations, business development consulting firms and organizations involved in contract manufacturing, product marketing and promotion, are not included in data sets due to their indirect implications on patent activities. To include all these alliances requires a comprehensive empirical design that eventually can present a true measurement of innovation

Journal of Technology Management for Growing Economies, Volume 3, Number 2, October 2012 
output. Future researchers should integrate the aspects of inter-organizational networking into a consensus-based theoretical conceptual framework or integrative model. The empirical design can be more efficient if other alliances that indirectly influence patented activities can be assimilated into more efficient empirical equations. The innovation output calculated in this research is from 2004 to 2006 because the available OECD variables are well defined in that time period in the OECD biotechnology 2009 report. Future researchers can take much more recent data sets from unconventional data sources, other than the OECD. Bioscan is one such website that provides recently updated paid data on the number of alliances and patent activities of firms, research organizations, partner universities and other firms throughout the world. This study combines processual qualitative and meta-analysis methods of quantitative research for comparative analysis. The findings clearly suggest that the biotech network One Nucleus has a positive impact on the innovation output of its sample member firms.

\section{REFERENCES}

Accenture and Babson College (2004) 'The Drug Industry's Aliance Archipelago', (online) (cited4 May 2010). Available from < URL:http://www.babsoninsight.com/contentmgr/showdetails.php/id/649>

Aharonson, B., Baum, J. and Feldman, M. (2004) 'Industrial clustering and the returns to inventive activity: Canadian biotechnology firms 1991-2000'. DRUID (Danish Research Unit for Industrial Dynamics) Working Papers, nos. 04-03.

Allen, R. (1983) 'Collective invention', Journal of Economic Behaviour and Organization, 4:1, pp. 1-24.

Anne, L.J. and Wal, T. (2011) 'The dynamics of the inventor network in german biotechnology: Ge ographical proximity versus triadic closure, Evolutionary Economic Geography, pp. 1102.

Arora, A. and Gambardella, A. (1990) 'Complementary and external linkages: The strategies of the large firms in biotechnology', Journal of Industrial Economics, 38:4, pp. 361-79. http://dx.doi. org/10.2307/2098345.

Arora, A. and Gambardella, A. (1994) 'Evaluating technological information and utilizing it', Journal of Economic Behaviour and Organization, 24:1, pp. 91-114.

Baker, A. (2003) 'Biotechnology's growth-innovation paradox and the new model for success', Journal of Commercial Biotechnology, 9:4 , pp. 286-88.

Baum, J.A., Calabrese, T. and Silverman, B. (2000) 'Don't go it alone: alliance network composition and startups' performance in Canadian biotechnology', Strategic Management Journal, 21:3, pp. 267-94. http://dx.doi.org/10.1002/(SICI)1097-0266(200003)21:3<267::AID-SMJ89>3.0.CO;2-8.

Beuzekom, B.V. and Arundel, A. (2009) 'OECD Biotechnology Statistics 2009' (online) (cited 18 June 2010). Available from < URL: http://www.oecd.org/dataoecd/4/23/42833898.pdf >

Butler, J.E. (1988) 'Theories of technological innovation as useful tools for corporate strategy', Strategic Management Journal, 9, pp. 15-29. http://dx.doi.org/10.1002/smj.4250090103.

Capello, R. (1999) 'Spatial transfer of knowledge in high technology milieux: Learning versus collective learning processes', Regional Studies. 33:4, pp. 352-65. http://dx.doi. org/10.1080/00343409950081211

Chin, J. (2004) 'Biotechnology's special forces: field based medical science liaisons', Journal of Commercial Biotechnology, 10:4, pp. 12-18. http://dx.doi.org/10.1057/palgrave.jcb.3040088.

Clark, J. (1979) A Model of Embodied Technical Change and Employment, Sussex, UK: Science and 
Verma, V.

Zoumpa, V. T.
Policy Research Unit, Sussex University.

Damanpour, F. and Gopoalakrishnan, S. (1999) 'Organizational Adaptation and Innovation: The Dynamics of Adopting Innovation Types', in Brockhoff, K., Chakrabarti, A. and Hauschild, J. (1 ${ }^{\text {st }}$ edn.) The Dynamics of Innovation, Berlin, Springer, pp. 57-80. http://dx.doi.org/10.1007/9783-662-03988-5_3.

DeBresson, C. and Amesse, F. (1991) 'Networks of innovators: A review and introduction to the issue', Research Policy, 20:5, pp. 363-79. http;//dx.doi.org/10.1016/0048-7333(91)90063-V.

Dutta, S. and Weiss, A.M. (1997), 'The relationship between a firm's level of technological innovativeness and its pattern of partnership agreements', Management Science, 43:3, pp. 343 56.

Ettlie, J.E. (1995) 'Product-process development integration in manufacturing', Management Science, 41:7, pp. 1224-1237. http;//dx.doi.org/10.1287/mnsc.41.7.1224.

Fox-Wolfgramm, S. J. (1997) 'Towards developing a methodology for doing qualitative research: the dynamic- comparative case study method', Scandinavian Journal of Management, 13:4, pp.439-455. http;//dx.doi.org/10.1016/S0956-5221(97)00028-6.

Edwards, T. (2000) 'Innovation and organizational change: developments towards an interactive process perspective. Technology Analysis and Strategic Management, 12:4, pp. 445-65. http:// dx.doi.org/10.1080/713698496.

Ettlie, J.E. (1995) 'Product-process development integration in manufacturing', Management Science, 41:7, pp 1224-1237.

Gans, J. and Stern, S. (2004) 'Managing ideas: commercialization strategies for biotechnology', (online) (cited 4 March 2010). Available from <URL:http://www.kellogg.northwestern.edu/ academic/biotech/articles/managing_ideas.pdf $>$

Garcia, C.Q. and Velasco, C.A. (2005) 'Agglomeration economies and vertical alliances: the route to product innovation in biotechnology firms', International Journal of Production Research, 43:22, pp. 4853-4873.

George, G. Zahra, S.A. and Wood, D.R. (2002) 'The Effects of Business-university Alliances on Innovative Output and Financial Performance: A Study of Publicly Traded Biotechnology Companies', Journal of Business Venturing, 17, pp. 577-609. http://dx.doi.org/10.1016/S08839026(01)00069-6.

Glass, A.M. Wokaun, A. and Heritage, J.P. (1981) 'Enhanced two-photon fluorescence of molecules adsorbed on silver particle films', Phys. Rev. B, 24:8, pp. 4906-4909. http://dx.doi.org/10.1103/ PhysRevB.24.4906.

Goerzen, A. and Beamish, P.W. (2005) 'The effect of alliance network diversity on multinational enterprise performance', Strategic Management Journal, 26:4, pp. 333-54. http://dx.doi. org/10.1002/smj.447.

Granovetter, M. (1998) 'Coase revisited: Business groups in the modern economy', in Dosi, G. Teece, D.J. and Chytry. J. (eds) New Technology, Organization and Competitiveness, York, Oxford University Press.

Gulati, R. (1995) 'Social structure and alliance formation patterns', Administrative Science Quarterly, 40:4, pp. 619-52. http://dx.doi.org/10.2307/2393756.

Gulati, R. and Higgins, M.C. (2003) 'Which ties matter when? The contingent effects of inter-organizational partnerships on IPO success', Strategic Management Journal, 24:2, pp.127-44. http:// dx.doi.org/10.1002/smj.287.

Hagedoorn, J. (1993) 'Understanding the rationale of strategic technology partnering: Interorganizational modes of cooperation and sectoral differences', Strategic Management Journal, 14:5, pp. 371-85. http;//dx.doi.org/10.1002/smj.4250140505.

Hinings, C.R. (1997) 'Reflections on processual research', Scandinavian Journal of Management, 13:4, pp. 493-503. http;//dx.doi.org/10.1016/S0956-5221(97)00023-7.

Hirschler, B. (2007) 'Biotech revenues top \$70 bln as M\&A premiums soar', (online) (cited on 28 September 2010). Available from <URL:http://www.reuters.com/article/idUSL1534079120070415

Johnson, J.D., Donohue, W.A., Atkin, C.K. and Johnson, S. (2001) 'Communications, involve-

Journal of Technology Management for Growing Economies, Volume 3, Number 2, October 2012 
ment and perceived innovativeness: test of a model with two contrasting innovations', Group and Organization Management, 26:1, pp. 24-52.

Kogut, B. (1988), 'Joint ventures: Theoretical and empirical perspectives', Strategic Management Journal, 9:4, pp. 319-32. http;//dx.doi.org/10.1002/smj.4250090403.

Kogut, B. (2000) 'the network as knowledge: Generative rules and the emergence of structure', Strategic Management Journal, 21:3, pp. 405-25. http://dx.doi.org/10.1002/(SICI)1097-0266( 200003)21:3<405::AID-SMJ103>3.0.CO;2-5.

Langlois, R.N. (1989) 'Economic change and the boundaries of the firm', in Carlsson, B. (eds) Industrial Dynamics, Technological Organizational and Structural Changes in Industries and Firms, Boston, Kluwer, pp. 85-108.

Larson, A. (1992) 'Network dyads in entrepreneurial settings: A study of the governance of exchange relationships', Administrative Science Quarterly, 37:1, pp. 76-104. DOI:10.2307/2393534.

Lavie, D. and Rosenkopf, L. (2006) 'Balancing exploration and exploitation in alliance formation', The Academy of Management Journal, 49:4, pp. 797-818.

Lippitt, R., Watson, J. and Westly, B. (1958) 'The dynamics of planned change’. New York: Harcourt. http://dx.doi.org/10.1177/002076406000500417.

March, J. (1991) 'Exploration and exploitation in organizational learning', Organization Science, $2: 1$, pp. 71-87.

Meyer, M.H. and Mugge, P.C. (2001) 'Make platform innovation drive enterprise growth', $R e$ search Technology Management, 44:1, pp. 25-39.

Milling, P.M. \& Stumpfe, J. (2000) 'Product and process innovation a system dynamics based analysis of the interdependencies', (online) (cited 26 September 2010). Available from <URL:http:// www.systemdynamics.org/conferences/2000/PDFs/milling1.pdf>

Mohr, J.J. \& Sengupta, S. (2002) 'managing the paradox of inter firm learning: The role of governance mechanisms'. Journal of Business \& Industrial Marketing, 17:4, pp. 282 -301. http://dx.doi.org/10.1108/08858620210431688.

Mowery, D.C., J.E. Oxley, and Silverman, B.S. (1998) 'Technological overlap and interfirm cooperation: Implications for the resource based view of the firm', Research Policy, 27:5, pp. 507-23. http://dx.doi.org/10.1016/S0048-7333(98)00066-3.

Nelson, A (2009) 'Measuring Knowledge Spillovers: What patents, licenses and publications reveal about innovation diffusion'. Research Policy, 38:6, pp. 994-1005. http://dx.doi.org/10.1016/j. respol.2009.01.023.

Oliver, C. (1990) 'Determinants of inter-organizational relationships: Integration and futuredirections'. Academy of Management Review, 15:2, pp. 241-65.

Oliver, A. (2001) 'Strategic alliances and the learning life-cycle of biotechnology firms' Organization Studies, 22:3, pp. 467-89. 10.1177/0170840601223004.

Orton, J.D. (1997) 'From Inductive to Iterative Grounded Theory: Zipping the Gap between Process Theory and Process Data', Scandinavian Journal of Management, 13:4, pp. 419-38. http:// dx.doi.org/10.1016/S0956-5221(97)00027-4.

Oxley, J.E. and Sampson, R.C. (2004) 'The scope and governance of international R\&D alliances', Strategic Management Journal, 25:89, pp. 723-49. http://dx.doi.org/10.1002/smj.391.

Ozman, M. (2009) 'Inter-firm networks and innovation: a survey of literature', Economic of Innovation and New Technology, 18:1, pp. 39-67. http://dx.doi.org/10.1080/10438590701660095.

Patton, M. Q. (1990) Qualitative evaluation and research methods. CA: Thousand Oaks. Sage.

Perreault,W. D. and Leigh, L. E. (1989) 'Reliability of nominal data based on qualitative judgments. Journal of Marketing Research, 26:2, pp. 135-148. http://dx.doi.org/10.2307/3172601.

Pettigrew, A.M. (1997) 'What is Processual Analysis? Scandinavian Journal of Management, 13:4, pp.337-48.

Pfeffer, J.and Salancik, M. (1978) 'The external control of organizations: A resource dependence perspective', New York. Harper and Row.

Pisano, G.P. (1997) 'The Development Factory: Unlocking the Potential of Process Innovation', HBS Press, Boston, Mass.
The Positive Impact

Journal of Technology Management for Growing Economies, Volume 3, Number 2, October 2012 
Verma, V.

Zoumpa, V. T.
Porter, M. (1990) 'The competitive advantage of nations', New York. Free Press.

Powell, W. (1990) 'Neither market nor hierarchy: Network forms of organization', Research in organizational Behaviour, 12, pp. 295-336.

Powell, W.W. Koput, K.W. and Smith-Doerr, L. (1996) 'Inter-organizational collaboration and the locus of innovation: networks of learning in biotechnology', Administrative Science Quarterly, 41:1, pp.116-45. http://dx.doi.org/10.2307/2393988.

Prahalad, C.K. and Mashelkar, R.A. (2010) 'Innovation's Holy Grail'. Harvard business review, (online) (cited 17 July 2009). Available from < URL:http://hbr.org/2010/07/innovations-holy-grail/ ar/1 >

Ring, P. and Van de Ven, H. (1994) 'Developmental processes of cooperative inter-organizational relationships', Academy of Management Review, 19:1, pp.90-118.

Schumpeter, J. (1934) 'The theory of economic development', Cambridge. MA. Harvard University Press.

Shan, W.Walker, G.and Kogut, B. (1994) 'Interfirm cooperation and startup innovation in the biotechnology industry', Strategic Management Journal, 15:5, pp. 387-94. http://dx.doi.org/10.1002/ smj.4250150505.

Soh, P. and Roberts, E.B (2003) 'Networks of innovators: A longitudinal perspective', Research Policy, 32:9, pp. 1569-88. http://dx.doi.org/10.1016/S0048-7333(03)00065-9.

Smith, O.J. and Powell, W (2004) 'Knowledge networks as channels and conduits: the effects of spillovers in Boston biotechnology community. Organization Science, 15:1, pp. 5-21. http:// dx.doi.org/10.1287/orsc.1030.0054.

Strauss, A.L. and Corbin, J. (1990) 'Basics of qualitative research: Grounded theory Procedures and techniques', London. Sage.

Summit Corporation Plc (2008) 'Summit plc enters into a co-development agreement with the Lilly tb drug discovery initiative for tuberculosis programme'. (online) (cited 26 September 2010). Available from: < URL http://www.summitplc.com/uploads/08_summ_13tbfinal.pdf >

Thorelli, H.B. (1986) 'Networks: Between markets and hierarchies', Strategic Management Journal, 7:1, pp. 37-51. http://dx.doi.org/10.1002/smj.4250070105.

Walker, G. Kogut, B. and Shan. W. (1997) 'Social capital, structural holes and the formation of an industry network', Organization Science, 8:2, pp. 109.

Wernerfelt, B. (1984) 'A resource-based view of the firm', Strategic Management Journal, 5:2, pp. 171-80. http://dx.doi.org/10.1002/smj.4250050207.

Williamson, O. (1991) 'Comparative economic organization: The analysis of discrete structural alternatives', Administrative Science Quarterly, 36:2, pp. 269-96. http://dx.doi. org/10.2307/2393356.

Whittington, K.B. and Smith, J.O. (2009) 'Networks, propinquity and innovation in knowledge intensive industries', Administrative Science Quarterly, 54, 90-112.

Wolf, F.M. (1986) 'Meta-analysis: quantitative methods for research syntheses, London. SAGE

Vivek Verma, is Post Graduate Student, School of Economics and International Business University of Greenwich, London, United Kingdom. Email: vv811@greenwich.ac.uk.

Vasilki T Zoumpa, is Lecturer, International Business and Economics Department, University of Greenwich, London, United Kingdom. Email: v.tzoumpa@ gre.ac.uk.

Journal of Technology Management for Growing Economies, Volume 3, Number 2, October 2012 